\title{
Corona, Theodicee en Job
}

\author{
Frank G. Bosman Q Archibald L.H.M. van Wieringen*
}

\begin{abstract}
Summary
Having a look at the public treatment of the corona pandemic, we can see reminiscents of the theodicy discussion in the Christian philosophical/theological tradition. The main treatments of the theodicy are Irenaean or Augustinian: either the evil was linked to some greater good, or the evil was linked to the human development. In the case of corona, both theodicies are present, although in a secular form. With the help of the book of Job, the authors argue that both theodicees fail and a biblical perspective of fighting the evil (along with God) without links to scapegoats or education is more fruitful.
\end{abstract}

Het was eind januari 2020. Corona (dan wel CoVid-19 veroorzaakt door het SARS-CoV-2-virus) was vanuit West-Europees oogpunt vooral een Aziatisch probleem met de focus op China, waar het virus als eerste de kop opstak. In eerste instantie gebeurde er in Nederland niets. Het Rijksinstituut voor Volksgezondheid en Milieu (RIVM) meldde dat we niets te vrezen hadden. Totdat corona zich ook in Nederland meldde...

Ondanks het feit dat de Nederlandse samenleving niet (meer) religieus bepaald is, viel het ons op dat in reacties op en discussie over corona de in wezen religieuze theodicee toch meer of minder expliciet aan de orde komt als antwoord op de vraag waarom ons dit kwaad treft. In dit artikel willen wij allereerst deze versluierd aanwezige corona-theodicee anekdotisch adstrueren $(\sqrt{1})$. Daarna zoomen we in op de theodicee zelf. Wij maken daarvoor gebruik van het standardwerk Evil and the God of Love van John Hick (1966), die een onderscheid maakt tussen het Irenaeïsche en het Augustiniaanse model. Dit onderscheid lijkt ons ook op te gaan in de aan de corona gekoppelde theodicee $(\mathbb{2}$ ). Vervolgens willen wij een laag dieper aanboren door de vraag te stellen of de theodicee überhaupt een geschikt antwoord is op de waaromvraag naar het kwaad. Vanuit het bijbelboek Job wordt ernstige kritiek geleverd op de theodicee als zodanig $(\mathbb{3}$ ). Deze kritiek zal blijken ook consequenties te hebben voor de corona-theodicee. Met behulp van het bijbelboek Job zijn deze

* Frank G. Bosman is cultuurtheoloog en als onderzoeker verbonden aan Tilburg School of Catholic Theology. Archibald L.H.M. van Wieringen is als hoogleraar Oude Testament daar werkzaam. 
niet alleen te bekritiseren, maar is het tevens mogelijk een nieuwe visie op de coronaproblematiek te ontwikkelen ( $\mathbb{4} 4)$.

\section{Anekdotisch overzicht van de corona-theodicee}

Waarom worden wij getroffen door corona? Waarom treft dit kwaad ons, goede mensen? Een klassieke vraag die in coronatijden meer of minder expliciet verwoord wordt. Binnen het kader van ons artikel voert het te ver om een algeheel overzicht van theodicee-gerelateerde reacties op corona op te stellen. Het gaat ons hier primair om het vaststellen van het feit dat deze reacties er zijn.

Eigenlijk begon de koppeling tussen corona en de theodicee met het carnavalsliedje 'Voorkomen is beter dan Chinezen' dat Lex Gaarthuis in februari voor Radioı maakte, waarin deze Radio1o-dj zijn publiek de 'raad' gaf: "Vreet geen Chinees, dan heb je niets te vrezen, want voorkomen is beter dan Chinezen." Traditioneel flauwe carnavalshumor; maar de reacties waren echter zó kritisch, dat zowel het radiostation als Gaarthuis door het stof gingen (Den Blanken 2020). Zelfs het Openbaar Ministerie deed onderzoek naar de strafbaarheid van het liedje, maar constateerde in juni dat het lied 'satirisch' moest worden opgevat (ANP 2020). Niet iedereen was het met die kwalificatie eens: antidiscriminatiebureau Radar startte in augustus - samen met een aantal andere organisaties - een zogenaamde artikel 12-procedure om het Openbaar Ministerie alsnog te dwingen de zaak voor de rechter te brengen (Van Leeuwen 2020).

Het was duidelijk dat de Chinezen - thuis en in het buitenland - in verband werden gebracht met wat later een pandemie zou worden genoemd, met achter dit verband het impliciet verwijt dat zij de schuldigen waren voor de coronaperikelen. Wereldwijd werden Chinezen met argusogen aangekeken of erger: "Chinese studenten die tijdelijk niet meer naar Frankrijk hoeven te komen. Restaurants in Korea en Japan die Chinese toeristen weren. Wereldwijd voelen Chinezen (en voor Chinezen aangeziene Aziaten) de reacties op de uitbraak van het coronavirus" (Huet 2020). Een reactie waarbij alle Chinezen over één kam werden geschoren, terwijl Europeanen uit de getroffen Chinese regio wél naar de EU mochten reizen, zelfs gerepatrieerd werden.

Naast het zondebokmechanisme (Tempelman 2020) doken ook andere reacties op de virusuitbraak op. Corona was een kwaad dat juist de ogen opende voor het goede dat tot dan toe niet of onvoldoende aandacht had gekregen. In april 2020 zag een meerderheid van de Nederlanders het virus als een positieve bijdrage aan het oplossen van de klimaatproblemen (Bijlo 2020). 
Anderen zagen het virus als een moment voor technische innovaties, thuiswerken, zorg voor elkaar of het geven van verdiende aandacht aan het zorgpersoneel (Vorward 2020).

Religieuze leiders reageerden eveneens gemengd (Marshall 2020). Sommigen dachten in de lijn van het zondebokmechanisme of zagen corona als een straf van God voor des mensen zondigheid. Anderen beschouwden de pandemie juist als een kans om spiritueel te groeien (Addonia 2021) en dankten God voor het inzicht dat de mens niet aan de macht is.

\section{Theodicees: in een religieuze en seculiere context}

In eerste instantie lijkt de combinatie van corona en theodicee een onmogelijke. De theodicee veronderstelt niet alleen een monotheïstische context, maar tevens een maatschappij die 'vanzelfsprekend' religieus is. De geseculariseerde, gedeïnstitutionaliseerde en multiculturele Nederlandse samenleving anno 2021 voldoet aan geen van beide voorwaarden (Bosman 2018). Maar niettemin blijkt de oude theodicee in de context van corona nog steeds relevant.

De theodicee is klassiek gekoppeld aan de vraag si deus est, unde malum (indien God er is, waar komt het kwaad dan vandaan?), verwoord door Godfried Leibniz in zijn Essais de Théodicée sur la bonté de Dieu, la liberté de l'homme et l'origine du mal (1710), gebaseerd op een tekst van Boethius (De consolatione filosofiae I, 4,30). Juist in een geseculariseerde context als die van de Nederlandse samenleving lijkt de theodicee aan intensiteit te winnen, zij het gebaseerd op de onuitgesproken vraag: si deus non est, unde malum? Als God niet meer aangewend (en eventueel veroordeeld) kan worden als oorzaak van het lijden, wie of wat dan nog wel? De twee historische hermeneutieken om van de theodicee, zoals onderscheiden door Hick, blijken ook nu weer hun rol te spelen in het moderne coronadebat, zij het wat verborgen en in aangepaste vorm.

\subsection{Si deus est, unde malum?}

De vraag naar het bestaan van het kwaad en van menselijk lijden is een bekende binnen de westerse filosofie (Inwagen 2006). Vanwege de historischchristelijke context van West-Europa is de vraag naar het lijden vrijwel altijd behandeld in relatie tot het bestaan van een persoonlijke God (Tilley 2000), die al reeds in het jodendom de eigenschappen van goedheid en almacht als vanzelfsprekend krijgt toebedeeld (Smith 2005). Ofschoon de bekende vraag 
si deus est, unde malum afkomstig is uit de werken van Boethius en Leibniz en laatstgenoemde het begrip 'theodicee' introduceerde, is het David Hume, die in 1779 het beroemde axioma als volgt formuleerde:

Is he [God] willing to prevent evil, but not able? Then is he impotent. Is he able, but not willing? Then is he malevolent. Is he both able and willing? Whence then is evil?

In de geschiedenis van filosofie en theologie zijn vele theodicee-oplossingen voor het probleem van het kwaad aangedragen (zoals opgesomd in Keller 2013). Hick evenwel ordent deze veelheid aan theodicee-oplossingen. In zijn beroemde boek Evil and the God of Love onderscheidt hij twee historisch dominante modellen, die hij koppelt aan twee invloedrijke theologen, te weten: Irenaeus van Lyon (140-202) en Augustinus van Hippo (354-430).

Irenaeus, aldus Hick, rechtvaardigt de algoede en almachtige God door het kwaad te interpreteren als een noodzakelijke voorbereiding voor het goede. In deze visie is God weliswaar verantwoordelijk voor het kwade, maar alleen ten behoeve van een ultiem 'goed'. De klassieke verdedigingen die gebruik maken van retributie (God straft de slechten), bescheidenheid (we kunnen God niet snappen), het idee van onze wereld als de beste van alle mogelijke werelden (Leibniz) of externalisatie (het kwade wordt veroorzaakt door duivels en/of demonen) vallen in deze Irenaeïsche categorie.

Augustinus, aan de andere kant, aldus Hick, rechtvaardigt niet zozeer het kwade, maar God zelf, door het kwade te interpreteren als een noodzakelijke consequentie van het goede. Niet God is op deze manier verantwoordelijk voor het kwade, maar mensen zelf: het kwade in de wereld is de consequentie van hun immoreel gebruik van de ingeschapen menselijke vrije wil. God heeft het kwade niet direct geschapen, maar toegestaan als consequentie en voorwaarde voor de radicaliteit van de vrije wil. In deze categorie vallen de klassieke verdedigingen van menselijke vrijheid en de privatio boni (het kwade is een wegroving van het goede). Augustinus' begrip privatio is dan ook geen descriptieve term, maar een appellerende.

\subsection{Si deus non est, unde malum?}

Dat de covid-19-pandemie in de categorie 'kwaad' valt, zal niemand willen ontkennen. In eerste instantie lijkt het te gaan om een natuurlijk kwaad zonder morele connotatie (Smit 2003), maar in veel discussies in media en maatschappij wordt de menselijke factor ook dikwijls nadrukkelijk genoemd. Sommige critici interpreteren de pandemie als een aanmaning van 'Moeder 
Aarde' die de mensheid wil waarschuwen op te houden haar uit te buiten. Alan Weisman (2020) vat dit sentiment fraai samen:

Calling this coronavirus Mother Nature's revenge is evocative, but ecology — the science of how everything connects - doesn't require a sentient, angry Gaia to smite us. (...) Nature's balance is a bloody pyramid scheme that, since everything's recycled, actually works, with multitudinous, prolific little critters below constantly being sacrificed to sustain the fewer but larger, more powerful predators above.

Andere critici wijzen op Chinese gastronomische gewoontes, die medeverantwoordelijk zouden kunnen zijn voor het prille begin van de pandemie. Voornamelijk vleermuizenconsumptie moet het ontgelden (Kang, Cheng \& McNeil 2020). Weer anderen wijzen op de rol van mensen in de verspreiding van het virus, omdat niet iedereen zich braaf aan de opgelegde coronaregels zou houden (Abrams 2020). Bovendien gaf de pandemie een nieuwe impuls aan complotdenkers, die vooral via QAnon (internationaal) of Viruswaanzin (nationaal) de kop op staken (Lewis 2020; Brodner et.al. 2020).

Als we naar de reacties kijken op de coronapandemie kunnen we grofweg twee verschillende 'rationele' reacties onderscheiden, in tegenstelling tot meer emotioneel gegronde reacties als angst of wanhoop. De eerste categorie aan reacties focust zich op het vinden van een (morele) instantie die verantwoordelijk gehouden kan worden voor de pandemie. In wezen is daarmee sprake van een zondebokmechanisme (Nieboer \& Berkhof 2020).

Natuurlijk, er zijn religieuze leiders - soms aan de flanken van hun confessie - die God en de coronacrisis aan elkaar koppelen (DeJesus 2020; Rahman 2020; De Korte 2020), echter niet om God ter verantwoording te roepen, maar om te verklaren dat God deze crisis gebruikt om ons iets te leren (Irenaeïsch) of dat we de ellende aan onszelf te danken hebben (Augustiniaans). Voor de gemiddelde geseculariseerde West-Europeaan is een dergelijke weg echter onbegaanbaar geworden, wil hij of zij niet zijn eigen zelfidentificatie trotseren.

Dus is het zoeken naar een andere instantie om de schuld te geven van de crisis, maar uiteraard niet God. En dit mechanisme is actief ondanks dat het strikt genomen om een amoreel kwaad gaat: immers, een (dit) virus is geen menselijke uitvinding. Niettemin moet dit kwaad ook een morele agens hebben en zodra deze, al dan niet met terechte argumenten omkleed, gevonden is, wordt hem/haar/het de schuld op de schouders geladen.

Marc Thiessen, de speechschrijver van president George W. Bush, wijst in een opiniestuk in The Washington Post (2020) ongegeneerd naar het China van president Xi Jinping voor een georganiseerde poging de uitbrekende 
pandemie in de doofpot te duwen. Jelle Reumer, emeritus-hoogleraar paleontologie (UU), vergelijkt de moderne toerist met de middeleeuwse ratten die de pest verspreidden. Voor het radioprogramma 'Vroege vogels' (BNNVARA, 15 maart 2020) zei hij:

Bij de kippengriep konden we er trekvogels nog de schuld van geven en bij varkenspest de wilde zwijnen, maar bij corona is geen sprake van trekvogels en zwijnen maar van toeristen. Met honderden tegelijk in de snelkookpan van de economy class zijn toeristen het moderne equivalent van de ratten die ons in de veertiende eeuw de pest brachten.

In het voorjaar van $2020 \mathrm{kreeg}$ ook het binnenlandse toerisme het verwijt zwaar aan de verspreiding te hebben bijgedragen. Vooral het carnavalsfeest van 23 tot en met 25 februari zou een super spreader voor met name ZuidNederland geweest zijn (Meeuwissen 2020). Ook kregen (en krijgen) de Nederlandse kerken geregeld het verwijt dat zij zich minder aan de coronamaatregelen zouden houden, hierbij leunend op hun grondwettelijke rechten (Houten \& Fijter 2020). Mede dankzij de mediale aandacht voor de megakerken op de Veluwe en elders in Nederland volgde zelfs de - nog voorzichtige - oproep om aan de vrijheid van godsdienst zelf te gaan morrelen (Voermans \& Jurgens 2020; Bosman 2020).

Een vergelijkbare discussie staat voor de deur met betrekking tot mensen die wel en die niet gevaccineerd (willen) zijn. Mensen die zich niet willen laten inenten, om religieuze redenen, maar ook om wetenschappelijke redenen, zouden de zondebok kunnen worden van de blijvende aanwezigheid van corona, met een apartheidstweedeling in de samenleving als uiteindelijk gevolg. In een artikel voor CNBC (Shead 2021) werd deze dreiging als volgt verwoord:

There is the potential for unvaccinated individuals to contract a serious case of coronavirus, which we take would be bad for them, but could also negatively affect others, for example, if health resources have to be diverted away from non-Covid care.

Naast deze seculier-Augustiniaanse hermeneutiek om de (morele) schuld van een (amoreel) kwaad te verplaatsen van een transcendente causaliteit naar een binnen-wereldlijke variant, zien we ook een seculier-Irenaeïsche soort omgang met corona optreden: het idee dat de pandemie ook haar eigen, verborgen lessen heeft en ons mensen nieuwe kansen en inzichten biedt. Het 
kwaad van de corona dient een hoger goed van nieuwe kansen. In de media treffen we eigenlijk vier soorten 'kansen' aan die de coronacrisis ons biedt.

In de eerste plaats zijn er kansen in financieel-economische zin (Ouwekerk 2020). De crisis dwingt bedrijven te innoveren, thuisbezorgingsdiensten draaien overuren, de webwinkels en de postdiensten kunnen de bestellingen niet meer aan en nieuwe digitale diensten vinden een markt. In de tweede plaats zijn er kansen in de sociaal-intermenselijke zin (Bosma 2020): mensen hervinden familieleden door het gedwongen thuiszitten en -werken, alleen de sterke, 'echte' vriendschappen overleven en voor de introverten onder ons is buigen gemakkelijker dan al die handen schudden, laat staan al dat gekus en gezoen bij elke sociale gelegenheid. Ten derde zien mensen, we spraken er al eerder kort over, kansen voor het klimaat (Bijlo 2020): passagiersvliegtuigen staan aan de grond, files bestaan bijna niet meer en kantoorpanden hoeven niet meer warm gestookt te worden. Sommige critici gaan hierin erg ver. Zo zegt trendwatcher Adjiedj Bakas in Trouw (2020), in een opmerkelijke parallel met de eerder geciteerde Jelle Reumer:

Corona is de nieuwe pest, en we leven in de nieuwe Middeleeuwen. Tijdens de grote pest in de Middeleeuwen ontstond een enorme innovatiegolf. In die periode is de boekdrukkunst uitgevonden en kwam de Reformatie op gang. Dat soort grote veranderingen gaan we nu ook zien. Maar voordat de nieuwe Renaissance aanbreekt, komt er nog veel ellende en veel onrust. Dat hoort er allemaal bij.

Van de renaissance is het een kleine stap naar de vierde soort kans die door mensen aan de coronacrisis wordt toegedicht: de spiritueel-religieuze (Roosendaal 2020; Beunders 2020). Hierin gaat het om esoterische begrippen als 'rust', 'ruimte', 'balans' en 'onthaasting'. De site Holistik.nl bijvoorbeeld vermeldt " 5 spirituele groeikansen die het coronavirus jou biedt" en onderscheidt hierin: kiezen voor angst of vertrouwen, oefenen in overgave, zorgvuldig en selectief zijn, individuele behoeftebepaling en het openen van je hart.

Mensen in deze categorie zien in de coronacrisis een kans om zich te onttrekken aan de verfoeide ratrace die het kosmopolitische, moderne leven kenmerkt, de sociale druk van ellenlange vergaderingen op locatie en vanzelfsprekend overwerk op kantoor, de even grote druk om er een hectisch en veelzijdig sociaal leven op na te houden, om altijd en even vanzelfsprekend carrière en zorgtaken te balanceren. Voor deze mensen kan corona de noodzakelijke reboot (herstart) zijn, een door externe omstandigheden gecreëerde kans om het eigen leven te evalueren en eventueel (definitief) bij te sturen. 


\section{Het Bijbelboek Job}

Hoezeer de theodicee ook het resultaat is van christelijke theologie en filosofie vanaf met name de $17^{\mathrm{e}}$ eeuw, de achterliggende vraag, waarom het kwaad goede mensen treft, is zo oud als de mensheid. In de wereld van het Oude Nabije Oosten, een van de oudste cultuurgebieden ter wereld, komt deze vraag al aan de orde in het Sumerische geschrift Mens en God (ANET 589-591), dat gewoonlijk rond 2000 voor onze jaartelling gedateerd wordt. Een man klaagt over het leed dat hem is overkomen, en bidt om redding tot zijn God. Deze verhoort hem en de man prijst hem daarop. In het verhaal wordt duidelijk dat het leed de man getroffen heeft, omdat dat voortkomt uit de zondigheid die de mens nu eenmaal vanaf zijn geboorte aankleeft. Het gaat in wezen meer om noodlot dan om een leerproces (Irenaeïsche theodicee) of ethisch appel (Augustiniaanse theodicee), maar omdat er sprake is van de menselijke zondigheid past het Sumerische geschrift nog het beste in het Augustiniaanse vakje. Zoals de anonimiteit van het hoofdpersonage laat zien, gaat het niet over deze of gene persoon, maar over een situatie die er gewoon voor iedereen is.

Ook de Bijbel bevat een boek over de vraag naar het onrecht dat goede mensen treft: het boek Job. Maar in tegenstelling tot de theodicee-oplossingen die in de christelijke filosofie en theologie geformuleerd zijn, kiest het boek Job niet voor een invalshoek die binnen ons theodicee-denken past. Het kwaad wordt niet gerechtvaardigd door het als een leerproces of een ethisch appel te zien. Wat doet het bijbelboek Job dan?

Job wordt getroffen door rampspoed. Zijn vee en kinderen komen om, zijn lijf wordt aangetast door ziekten. Hij belandt op de mestvaalt of, beter geformuleerd, in de askuil. Daar krijgt hij bezoek van drie vrienden, Elifaz, Bildad en Zofar. Zij claimen de reden van zijn rampspoed wel te kennen. In de hoofdstukken 4-28 formuleren de drie vrienden drie verklaringen (Engljähringer 2003). Deze drie verklaringen passen enerzijds in de latere categorieën van Irenaeïsche en Augustiniaanse theodicee (Gray 2011), anderzijds in het (Sumerische) noodlotsdenken in de antieke wereld.

Het leed is het gevolg van menselijke zonde. En Job moet niet doen alsof hij geen zonden heeft, want dan zijn er altijd wel verborgen zonden (Job 15:1416). Deze eerste idee sluit het beste aan bij wat wij hiervoor hebben gezien als de Irenaeïsche theodicee: het lijden dat Job treft is een leerschool om zijn eigen zondigheid te erkennen en te bezien, een leerschool die je zelfs toegang geeft tot je meest verborgen zondigheid. Maar het heeft tevens aspecten van 
de Augustiniaanse theodicee, omdat het een ethisch beroep doet op het overkomen van de zondigheid.

De tweede verklaring ziet het leed als een goddelijke opvoeding door terechtwijzing. In de antieke cultuur was het de vader die door tucht en straf zijn kinderen opvoedt; geen kind vindt het leuk straf te krijgen, maar het plukt er later wel de vruchten van. Uitdrukkingen van deze opvoedingswijsheid vinden we in het hele Oude Nabije Oosten, in Mesopotamië zowel als Egypte, en dus ook in de Bijbel, met name in de boeken Spreuken en Ben Sirach. Ook deze tweede idee sluit aan bij de Irenaeïsche theodicee. Het lijden dat Job treft is een leerschool om zijn eigen zondigheid te erkennen en te bezien, een leerschool die je zelfs toegang geeft tot je meest verborgen zondigheid. Als derde verklaring wordt het idee geformuleerd dat het leed verbonden is aan de menselijke natuur. Job 4:19 drukt het plastisch uit: de mens bewoont een lemen huis. En zo sterk is een constructie van leem niet; geen wonder dat lijden de mens treft. Dus eigenlijk doet de zondigheid van de mens er helemaal niet toe, want lijden is gewoon eigen aan het menselijk bestaan. De klassieke noodlotsgedachte klinkt in deze derde idee door: het gaat niet om goed of fout, om ethiek of leerproces, het is gewoon zo.

Job wijst de ideeën van zijn vrienden af en formuleert in plaats daarvan in de hoofdstukken 29-31 een aanklacht tegen God. Omdat de drie vrienden niet weten hoe daarop te reageren, duikt Elihu op om het woord te voeren. Hij had tot dan toen blijkbaar gezwegen omdat de drie ouder waren dan hij, maar nu neemt hij verontwaardigd het woord. Hij herneemt de theologieën van zijn drie voorgangers, maar voegt daar expliciet de idee van de beproeving van de rechtvaardige aan toe. Daarmee voorkomt hij niet alleen de discussie over de vraag of Job toch niet in het geniep gezondigd heeft, maar heeft hij ook de mogelijkheid de geloofsgroei van Job te benadrukken. Vanuit de twee theodicee-theologieën bezien, formuleert Elihu in wezen een Irenaeïsche theodicee, waarbij niet de vraag centraal staat of men van zijn fouten leert, maar dat men door beproeving leert.

Job is echter niet overtuigd. Hij vindt dat God hem onrecht aangedaan heeft en wenst hem daarop aan te spreken door zijn rechtszaak tegen hem door te zetten. Toch vindt de rechtszaak tegen God niet plaats. Niet omdat Jobs protest tegen het kwaad ongerechtvaardigd zou zijn, noch omdat God niet verantwoordelijk zou kunnen worden gehouden voor zijn eigen goddelijke daden, maar omdat Jobs beschuldiging aan het verkeerde adres blijkt gericht te zijn. In het bijbelboek Job openbaart God zichzelf in de slotredes in de hoofdstukken 38-42 niet als degene die verantwoordelijk is voor het kwaad, maar als degene die, samen met Job, tegen het kwaad is en het bestrijdt door 
de schepping te veroveren op een chaotische omgeving die voortdurend vatbaar voor deconstructie is (Schuman 2011).

Maar daarmee is de theodicee-kwestie in het boek Job nog niet af. De kwestie ligt nóg complexer. De tekst-immanente lezer beschikt immers over meer informatie dan de verhaalpersonages Job, zijn drie vrienden en de vierde spreker die opduikt. De lezer weet waarom Job getroffen is met rampspoed: de hoogste ambtenaar aan het koninklijk hof van God (de Hebreeuwse aanduiding van zijn functie is sātān) heeft zijn Heer uitgedaagd door Jobs geloof en vroomheid in twijfel te trekken. Niet God beproeft daarop Job, maar hij staat deze ambtenaar toe zijn gelijk te bewijzen, wetende dat deze dat niet zal kunnen. In het narratieve slot van het boek Job is deze falende ambtenaar dan ook verdwenen.

Daarmee weet de lezer tevens dat de drie verklaringen van Jobs drie vrienden geen stand kunnen houden. Het is dan ook geen verrassing dat God zich keert tegen de vrienden en sympathiseert met Job, die hij de bijbelse eretitel dienstknecht geeft:

Toen zei de Heer tot de Temaniet Elifaz: Mijn toorn is ontstoken tegen jou, en tegen je twee vrienden, want jullie hebben niet recht van mij gesproken, gelijk mijn dienstknecht Job (Job 42:7b).

Jobs visie is correct: er moet geprotesteerd worden. Maar dan wel een protest aan het juiste adres.

De tekst-immanente lezer heeft op deze wijze toegang tot de visie van God. Omdat God evenwel alleen de drie vrienden van Job bespreekt en niet de visie van Elihu, is het aan de tekst-immanente lezer Elihu's visie zelf te evalueren. Enerzijds mist Elihu de kern van Gods visie dat God primair de bestrijder van het kwaad is, niet de veroorzaker ervan. Daarmee is Elihu's opvatting niet in lijn met de door God geformuleerde slotvisie. Anderzijds speelt in Elihu de idee van beproeving. Weliswaar is het Gods hoogste ambtenaar die de beproeving voor zijn rekening neemt, maar de idee van beproeving en loutering wordt als zodanig niet aan het slot van het boek Job afgewezen. Dit geeft de tekst-immanente lezer de optie de bestrijding van het kwaad (ook) als een beproeving te verstaan. 


\section{Corona en theodicee óf corona en het bijbelboek Job?}

Het bijbelboek Job biedt de mogelijkheid om de twee theodicee-richtingen, de Augustiniaanse en Irenaeïsche, onder kritiek te stellen. Beide worden door het boek Job in wezen als niet functioneel gezien. Sterker, het alternatief dat het bijbelboek Job aanreikt, zou wel eens vruchtbaar kunnen zijn ook voor onze visie op de coronaproblematiek.

We kijken eerst naar de seculiere variant van de Augustiniaanse theodicee in de coronaproblematiek. Deze levert ons op korte termijn een zondebok op, hetzij een externe (Chinezen, buitenlandse toeristen) hetzij een interne ('wij' houden ons niet aan de maatregelen), maar biedt geen afdoende verklaring van het kwaad op middellange of lange termijn. Omdat geen enkele beschuldiging lang kan standhouden - ze zijn immers niet in de feitelijke realiteit gegrond, al was het maar dat geschikte data hiervoor simpelweg ontbreken (we komen hier in het vervolg nog op terug) - moet er steeds opnieuw een doelwit gezocht worden om de morele schuld voor de amorele ramp op de schouders te nemen, of liever gezegd, te krijgen.

In dit proces dreigt feitelijk geen enkele maatschappelijke, etnische of sociologische groep veilig te zijn voor de beschuldiging de oorzaak te zijn of in ieder geval mee te hebben gewerkt aan de verspreiding van de besmettelijke ziekte. Vanwege het afwezig zijn van een verankering in de empirische realiteit, kan een dergelijke beschuldiging op iedereen vallen, daartoe uitgeroepen door een amorfe massa van opinieleiders, politici, volksmenners, journalisten en (door de overheid ingehuurde) influencers (cf. Rietveld 2020). Behalve dat een dergelijke beschuldiging willekeurig is, valt zij ook nauwelijks effectief te ontkennen, precies omdat de beschuldiging niet rationeel gegrond is.

De laatste - en meest onverkwikkelijke - stap in deze seculiere theodicee is dat de aangewezen 'daders' van de pandemie worden vergeleken met subhumane levensvormen als kakkerlakken, insecten en/of knaagdieren. Zowel bij Reumer als Bakas zagen we deze stap al materialiseren: beiden spreken over de verspreiders van de ziekte als 'ratten', waarmee een duistere metafoor wordt opgeroepen van gedehumaniseerde wezens die geen rechten meer hebben en wiens collectieve uitroeiing als een haalbaar en zelfs wenselijk plan wordt gezien om de ramp af te wenden. We weten allen wat een dergelijke ontmenselijkende retoriek in onze recente geschiedenis teweeg heeft gebracht.

De beperkte 'houdbaarheid' van (nieuwe groepen) daders, de willekeurigheid waarmee deze worden aangewezen, de onmogelijkheid tot een effectieve bestrijding van de beschuldiging en de ontmenselijkende retoriek die op de loer ligt, maakt de seculier-Augustiniaanse hermeneutiek gevaarlijk. Dat wil 
zeggen, als de schuldvraag geëxternaliseerd wordt in 'de ander', zeker als die ander uitgesloten en uitgestoten zou dreigen te worden.

Een andere mogelijke uitkomst van deze hermeneutiek is die van zelfreflectie en een zelfidentificatie als dader. De individuele burger aanvaardt zijn of haar eigen rol in het scheppen van de (wereldwijde) voorwaarden waarbinnen een dergelijk virus zich kon ontwikkelen en verspreiden. 'Wij allemaal zijn schuldig,' is dan het devies. Behalve dat deze hermeneutiek kan leiden tot zelfreflectie en zelfs aanpassing van het individuele en collectieve gedrag, geldt ook hier voorzichtigheid vanwege het gevaar van de geprivilegieerde positie. Niet iedereen heeft de luxe deze reflectie te kunnen maken en bevindt zich in de geprivilegieerde positie, waarin de emotionele, financiële en praktische voorwaarden gerealiseerd zijn zich aan dergelijke reflecties over te geven. Voor vele burgers in Nederland en daarbuiten is de realiteit anders. Ze zijn ziek geworden of hebben geliefden die dat geworden zijn, sommige van hen zijn gestorven of hebben definitief afscheid moeten nemen van hun geliefden. Weer anderen hebben hun baan verloren of hun eigen zaak failliet zien gaan, of moeten leven met de continue dreiging dat dit bij de continuering van maatschappelijk ingrijpende maatregelen en regels zal gaan gebeuren. Anderen kennen geen geriefelijke, stille en comfortabele thuissituatie omdat die verscheurd wordt door spanningen van verplicht op elkaars lip levende huisgenoten of vanwege het gebrek aan fysieke ruimte om te werken of geschikte apparatuur. Maar niet alleen het gevaar van de geprivilegieerde positie dreigt, ook het gevaar dat binnen deze reflectie toch - stiekem - nieuwe externe daders worden aangewezen, die (het merendeel van) de schuld op de nek geladen kunnen krijgen, zoals de internationale handel, de luchtvaart of de toeristenindustrie. En ook deze collectieven kunnen worden teruggebracht tot de mensen die er werken of (en vooral) die daar een leidinggevende positie bekleden, waarna de duistere kant van deze hermeneutiek weer begint te spelen.

Ook de seculiere variant van de Irenaeïsche theodicee heeft schaduwkanten. Deze variant bevat het risico dat zij de afgrondelijkheid van het (immorele) kwaad niet serieus neemt en/of niet weet te verdisconteren, naast het feit dat - nog meer dan bij de seculier-Augustiniaanse - het gevaar van bevoorrecht-zijn nog sterker aanwezig is. Wie zijn baan, huis, bedrijf, relatie en geliefden heeft moeten afgeven tijdens en door de coronacrisis heeft de praktische en spirituele ruimte niet om zich aan een dergelijke hermeneutiek over te geven, uitzonderingen daargelaten.

De seculier-Irenaeïsche theodicee leert dat achter elke (moreel of amoreel) kwaad een hogere 'zin' bestaat, die vaak echter aan het onmiddellijke zicht 
wordt onttrokken. Dit veronderstelt niet alleen dat individuele mensen in staat zijn zich voor zo'n zich nog ontvouwende toekomst open te stellen (vertrouwen), maar ook dat zo'n toekomst daadwerkelijk tot bestaan zal komen (geloof). Het gaat hierbij niet om de banaliteit dat ook uit een crisis iets te leren valt, maar dat wat geleerd wordt de 'zin' van de crisis openbaart.

De Irenaeïsche theodicee, in tegenstelling tot de Augustiniaanse, neemt in zekere zin een voorschot op een betere toekomst, waarvoor de in het heden ervaren ellende een voorwaarde is of tenminste een tijdelijk oponthoud. Waar in premoderne tijden het bestaan van deze betere toekomst vanzelfsprekend was, aangezien deze door God zelf gegarandeerd werd en aan wiens bestaan niemand serieus twijfelde, bestaat in onze moderniteit een dergelijke garantie niet meer, of althans is deze niet meer voor iedereen vanzelfsprekend. Het succes van deze hermeneutiek hangt dus af van het menselijk vermogen te vertrouwen op en te geloven in een zich nog te ontvouwen toekomst. Mocht deze toekomst zich echter niet op korte of middellange termijn voordoen en mocht intussen het lijden zich continueren, dan wordt het navenant moeilijker deze hermeneutiek effectief in te zetten. Met andere woorden: de Irenaeïsche theodicee, in haar seculiere variant, weet geen weg met het persistente karakter van kwaad en lijden in onze wereld, maar slechts met een tijdelijke aanwezigheid hiervan.

Deze duistere kanten van de theodicees zijn ook aanwezig in de verhoudingen tussen de verhaalpersonages in het bijbelboek Job. Jobs vrienden zijn boos. Maar wonderlijk genoeg niet zozeer op de rampspoed die Job getroffen heeft, maar op Job zelf. Ze vinden hem eigenwijs, een zondaar zonder zelfkennis, omdat hij weigert zijn schuldigheid te erkennen. Het helpt Job geenszins verder, het helpt wel theodicee-ideologieën te promoten. Jobs vrienden proberen de baas te zijn, zelfs over wat Job van zichzelf zou moeten denken. Zeggen dat iemand zondig is, omdat er wel ergens een geheime zonde zal bestaan bij die persoon, leidt tot een altijd kloppende redenering. Een theodicee-ideologie die ook in de coronatijd weerklank vindt: de maatregelen tegen corona werken niet, dus hebben de burgers van Nederland gezondigd. En als ze beweren niet gezondigd te hebben, komt dat alleen maar door het feit dat ze zich niet bewust zijn van hun onbewuste zondigheid. Maar misschien klopt de theodicee-ideologie niet en zijn er gewoon verkeerde maatregelen genomen...

De theocidees lopen vast. Voor theologen zou dat eigenlijk geen verrassing moeten zijn, het bijbelboek Job laat dat al zien. Niet de theodicee werkt, maar de spanning tussen de chaos bestrijdende God van Israël en de wanorde waarmee mens en God geconfronteerd worden. Het is juist deze spanning die een 
werkbare context oplevert. Systematisch-theologisch geformuleerd gaat het om de spanning tussen een betrouwbare God en een imperfecte schepping. Omdat God, de Schepper, betrouwbaar is, is zijn schepping betrouwbaar. Het bestuderen van de schepping, het achterhalen van natuurwetten, is daarmee niet alleen mogelijk, maar zelfs een zinvolle en noodzakelijke activiteit.

De God van Israël wordt niet beleden als almachtig omdat hij morgen bijvoorbeeld de zwaartekracht zou kunnen afschaffen. Dat kan God niet omdat daarmee zijn schepping onbetrouwbaar wordt en daarmee hij zelf eveneens. De Latijnse uitdrukking omnipotens voor God was oorspronkelijk omnitenens: hij die het al in stand houdt. Wat er ook gebeurt, hemel en aarde, het universum, dondert niet in elkaar. Onder invloed van Irenaeus van Lyon is de aanduiding omnitenens vervangen door omnipotens, met alle mogelijke misverstanden van dien (Smulders 1977). Ook virussen beantwoorden aan wetmatigheden - wetmatigheden waarvan we beslist nog niet alle aspecten kennen, maar we tasten niet in het duister, we worden immers niet voor het eerst met een virus geconfronteerd. Voortbouwend op bestaande kennis, voorzien van niet-vervuilde data (de data-verzameling en -presentatie vanwege het RIVM is chaos, zich bijvoorbeeld uitend in het gebruik van het absolute aantal positieve PCR-testen, die aanvankelijk met 3 en vanaf medio augustus met 1 primer uitgevoerd worden [bijv. Hyungjin Kim et al. 2020; HospiMedica International 2021]) en gebaseerd op meer dan alleen modellen (de gemodelleerde mortaliteit bedroeg 3,4\%, maar bleek later o,2\% te zijn [bijv. Ioannidis 2020; Nyst 2021]), leidt nieuw wetenschappelijk inzicht in de virus-wetmatigheden tot nieuw inzicht en daarmee tot een betere bestrijding en genezing van virusziekten. Daar hebben we geen theodicee-verhaal voor nodig.

De andere pijler is de imperfectie van de schepping. Bijvoorbeeld dat wij mensen sterfelijk zijn. De Bijbel doet daar niet zo moeilijk over: de mens is sterfelijk geschapen (Van Wieringen 2015). Er is dan ook geen zondigheid die de dood in de wereld heeft gebracht. Er is volgens het verhaal van de Hof van Eden in Genesis 4 wél zondigheid die de mens de toegang tot de boom des levens heeft ontzegd. Misschien moeten we daar wel blij mee zijn: behept met de kennis van goed en kwaad kan het leven ook zwaar zijn, en als dat dan eeuwigdurend is... Hoe dat ook zij, de dood als resultaat van de zondigheid ontstaat pas onder invloed van het hellenisme in de tweede eeuw voor onze jaartelling.

Aan virussen kunnen mensen sterven; zo ook aan corona, maar dat is niet te vergelijken met ziektes als ebola, of de door ratten overgebrachte pest. Verreweg de meeste overledenen zijn oud en/of hebben onderliggend lijden. $\mathrm{Nu}$ de babyboomgeneratie, geboren in 1945-1955, in de leeftijd van 65-75 jaar 
zit, zal voor hen eerder een toename van het aantal ziekenhuisbedden nodig zijn dan de door bezuinigingen afgedwongen afname, zoals, toen deze generatie kind was, er meer scholen nodig waren. Zo gaat dat met sterfelijke mensen. Daar hebben we geen theodicee-verhaal voor nodig. Naar onze mening gaat het fout als een van deze pijlers, of dit nu binnen een gelovige, al dan niet geïnstitutionaliseerde, context is of niet, wordt verabsoluteerd, om vervolgens te vervallen tot bekende theodicee-verhalen in eventueel een nieuw jasje.

Wetenschappelijke integriteit, dat wil zeggen het recht doen aan de spanning tussen beide pijlers die in het boek Job zichtbaar worden, voorkomt een verabsolutering van uitersten en daarmee tevens de vermeende noodzaak naar theodicees te (moeten) grijpen. Jobs vrienden vallen Job aan, onder meer omdat hij zijn zondigheid niet onderkent, zoals dat past bij een van de theodicee-hermeneutieken. Daarmee trekken ze Jobs integriteit in twijfel. In feite willen ze Job dwingen in de mal van hun theodicee-ideologie te passen. Maar Job behoudt zijn integriteit en weigert. God blijkt hem daarin te steunen, waarmee hij het in wezen niet-integere gedrag van Jobs vrienden blootlegt. En elke theodicee met recht afwijst. Nu wij nog.

\section{Literatuur}

Abrams, D. (2020),

To solve the problems of this pandemic, we need more than just 'the science', in: The Guardian.com, 29 april, https://www.theguardian.com/education/2020/apr/29/ to-solve-the-problems-of-this-pandemic-we-need-more-than-just-the-science [bezocht op o6-01-2021].

Addonia, S. (2021),

Vrees de eenzaamheid niet, maar zoek ze op, in: Standaard.be, 2 januari, https://www. standaard.be/cnt/dmf20210101_97686866 [bezocht op o6-01-2021]. ANET

Pritchard, James B. (red.), Ancient Near Eastern Texts Relating to the Old Testament, 3rd ed., Princeton: Princeton University Press, 1969.

ANP (2021),

Dj Radio 10 wordt niet vervolgd vanwege 'coronalied', in: NOS.nl, 4 april, https://nos. nl/artikel/2336199-dj-radio-10-wordt-niet-vervolgd-vanwege-coronalied.html [bezocht op o6-01-2021]. 
Bakas, A. (2020),

Moeder Natuur haat ons: dit zal niet de laatste pandemie zijn, in: Trouw.nl, 4 juni, https://www.trouw.nl/religie-filosofie/moeder-natuur-haat-ons-dit-zal-niet-de-laatstepandemie-zijn b24bfog8/ [bezocht op ०6-01-2021].

Beunders, H. (2020),

Het 'irrationele' wint aan kracht in deze nieuwe 'Era Vaccina', in: NRC.nl, 30 december, https://www.nrc.nl/nieuws/2020/12/30/het-irrationele-wint-aan-kracht-in-dezenieuwe-era-vaccina-a4025681 [bezocht op o6-01-2021].

Bijlo, E. (2020),

Meerderheid Nederlanders ziet coronavirus ook als een kans voor het klimaat, in: Trouw.nl, 6 april, https://www.trouw.nl/nieuws/meerderheid-nederlanders-zietcoronavirus-ook-als-een-kans-voor-het-klimaat b9affee6/ [bezocht op o6-01-2021].

Blanken, M. den (2020),

Radio 10 diep door het stof na golf van kritiek op lied over coronavirus, in: $A D . n l$, 8 februari, https://www.ad.nl/show/radio-1o-diep-door-het-stof-na-golf-van-kritiekop-lied-over-coronavirus a74fe284/ [bezocht op o6-01-2021].

Bosma, R. (2020),

Corona is een kans voor nieuwe etiquette, in: Parool.nl, 12 maart, https://www.parool. nl/nieuws/corona-is-een-kans-voor-nieuwe-etiquette bo4a898f/ [bezocht op o6-o12021].

Bosman, F.G. (2018),

God is hier al! Over geloof, cultuur en theologie, Berne: Heeswijk.

Bosman, F.G. (2020),

Politiek speelt met de vrijheid van godsdienst, in: Katholiek.nl, 29 mei, https://www. katholiek.nl/opinie/politiek-speelt-met-de-vrijheid-van-godsdienst/ [bezocht op o601-2021].

Brodner, J., W. Welch \& I. Brodie (2020),

Covid-19 conspiracy theories. QAnon, ${ }_{5} G$, the New World Order and other viral ideas, Jefferson: McFarland.

DeJesus, I. (2020),

Faith leaders reject the idea that coronavirus is punishment from God for a sinful world, 25 maart, https://www.pennlive.com/coronavirus/2020/03/faith-leaders-rejectthe-idea-that-coronavirus-is-punishment-from-god-for-a-sinful-world.html [bezocht op 04-03-2021].

Engljähringer, K. (2003),

Theologie im Streitgespräch. Studien zur Dynamik der Dialoge des Buches Ijob, Stuttgarter Bibelstudien 198, Stuttgart: Katholisches Bibelwerk. 
Gray, M. (2011),

Pathways of interpretation. Facing God without flinching or the Elihu option?, in: Irish Biblical Studies, 29, 2-30.

Hick, J. (1966),

Evil and the God of Love, London: Macmillan.

HospiMedica International (2021),

WHO Changes SARS-CoV-2 Virus Test Criteria to Reduce False Positives, 25 januari, https://www.hospimedica.com/covid-19/articles/294786705/who-changes-sars-cov2-virus-test-criteria-to-reduce-false-positives.html [bezocht op 04-03-2021].

Houten, M. van \& N. de Fijter (2020),

Ingrijpen bij kerken kan wel degelijk, maar is het nodig?, in: Trouw.nl, 16 december 2020, https://www.trouw.nl/religie-filosofie/ingrijpen-bij-kerken-kan-wel-degelijkmaar-is-het-nodig b9bfa852/ [bezocht op ०6-01-2021].

Huet, Bob van (2020),

Chinezen worden gemeden, gepest en gediscrimineerd vanwege coronavirus, in: AD.nl, 31 januari, https://www.ad.nl/buitenland/chinezen-worden-gemeden-gepesten-gediscrimineerd-vanwege-coronavirus af94bd15/ [bezocht op o6-01-2021].

Hume, D. (2017[1779]),

Dialogue concerning natural religion, London: Taylor and Francis.

Inwagen, Peter van (2006),

The problem of evil, Oxford: Oxford University Press.

Ioannidis, J.P.A. (2020),

The infection fatality rate of COVID-19 inferred from seroprevalence data, in: Bulletin of the World Health Organization, doi: 10.2471/BLT.20.265892, 14 oktober, https:// www.who.int/bulletin/online_first/BLT.20.265892.pdf [bezocht op 04-03-2021].

Kang, D., Cheng, M. \& S. McNeil (2020),

China slamps down in hidden hunt for coronavirus origin, in: APNews.com, 30 december, https://apnews.com/article/united-nations-coronavirus-pandemicchina-only-on-ap-bats-24fbadc58cee3a4obca2ddf7a14d2955 [bezocht op o6-01-21].

Keller, T. (2013),

Walking with God through pain and suffering, New York: Riverhead Books.

Kim, Hyungjin, Hyunsook Hong \& Soon Ho Yoon (2020),

Diagnostic Performance of CT and Reverse Transcriptase Polymerase Chain Reaction for Coronavirus Disease 2019: A Meta-Analysis, RSNA Radiology, 17 april, https://doi. org/10.1148/radiol.2020201343 [bezocht op 04-03-2021],

Korte, de G. (2020),

God en Corona: Straf van God? Een beschouwing in het licht van kruis en opstanding, https://www.bisdomdenbosch.nl/god-en-corona-een-beschouwing-in-het-licht-vankruis-en-opstanding/ [bezocht 04-03-2021]. 
Leeuwen, M. van (2020),

Antidiscriminatiebureaus eisen vervolging Radio 10-dj om coronalied, in: AD.nl, 25 augustus, https://www.ad.nl/show/antidiscriminatiebureaus-eisen-vervolgingradio-10-dj-om-coronalied a 415440e/ [bezocht op o6-01-2021].

Leibniz, G.W. (1910),

Essais de Théodicée sur la bonté de Dieu, la liberté de l'homme et l'origine du mal, Amsterdam: Troyel.

Lewis, T. (2020),

Eight persistent covid-19 myths and why people believe them, in: Scientific American. com,12 oktober, https://www.scientificamerican.com/article/eight-persistent-covid19-myths-and-why-people-believe-them/ [bezocht op o6-01-2021].

Marshal, K. (2020),

What Religion Can Offer in the Response to COVID-19, 26 mei, https://www. worldpoliticsreview.com/insights/28789/religion-and-covid-19-faith-during-apandemic [bezocht op 04-03-2021].

Meeuwissen, M. (2020),

Weinig optochten tijdens carnaval 2020, ongemerkt wel carnavalsvierders met corona in de kroegen, in: OmroepBrabant.nl, 23 december, https://www.omroepbrabant. nl/nieuws/3312331/weinig-optochten-tijdens-carnaval-2020-ongemerkt-welcarnavalsvierders-met-corona-in-de-kroegen [bezocht op o6-01-2021].

Nieboer, B. \& F. Berkhof (2020),

Zoeken naar een zondebok bij corona lijkt een heilloze weg, in: Volkskrant.nl, 15 juli, https://www.volkskrant.nl/columns-opinie/zoeken-naar-een-zondebok-bij-coronalijkt-een-heilloze-weg b9b26806/ [bezocht op o6-01-21].

Nyst, E. (2021),

'Blijkbaar moeten we bang zijn': Artsen Covid Collectief pleit voor breder perspectief, interview met Evelien Peeters, in: Medisch Contact, 7, 18 februari.

Ouwekerk, G. (2020),

Corona biedt kans voor nieuwe online markten, in: Telegraaf.nl, 30 september, https:// www.telegraaf.nl/financieel/905618071/corona-biedt-kans-voor-nieuwe-onlinemarkten [bezocht op 06-01-2021].

Rahman, S. (2020),

Coronavirus Is Not Disease But Punishment For Our Sins By God: Samajwadi Party MP, 21 juli, http://www.businessworld.in/article/Coronavirus-is-not-disease-butpunishment-for-our-sins-by-God-Samajwadi-Party-MP-/21-07-2020-299831/ [bezocht 04-03-2021]. 
Reumer, J. (2020),

'Toeristen verspreiden corona, zoals ratten de pest', 15 maart, https://www.nporadio1. nl/natuur-milieu/22303-corona-door-toerisme-moderne-equivalent-van-ratten-dieons-pest-brachten [bezocht op 04-03-2021].

Rietveld, M. (2020),

Zondebok, 20 mei, htps://www.binnenlandsbestuur.nl/sociaal/opinie/columns/ zondebok.13300335.lynkx [bezocht 04-03-2021].

Roosendaal, M.-Th. (2020),

Gedwongen onthaasting: 'Ik vond lockdown een zegen, in: Telegraaf.nl, 24 mei, https:// www.telegraaf.nl/nieuws/1275019987/gedwongen-onthaasting-ik-vond-lockdowneen-zegen [bezocht op ०6-01-2021].

Schuman, Niek (2011),

Goed en kwaad, in: Spronk, Klaas \& Archibald van Wieringen (red.), De Bijbel theologisch, Zoetermeer: Meinema, 310-320.

Shead, S. (2020),

What people might not be allowed to do if they don't get vaccinated, 6 januari, https:// www.cnbc.com/2021/01/06/what-people-might-not-be-allowed-to-do-if-they-dont-getvaccinated.html [bezocht op 04-03-2021].

Smit, J. (2003),

Are catastrophes in nature ever evil?, in: Drees, W. (ed.), Is nature ever evil? Religion, science and value, London: Routledge.

Smith, B. (2005),

The tension between God as righteous judge and as merciful in early Judaism, Oxford: University press of America.

Smulders, Pieter (1982),

Belijdenis en leer, in: Boer, S. de \& M.B. Pranger (red.), Saecula saeculorum. Opstellen aangeboden aan C.W. Mönnich, Amsterdam: Athenaeum-Polak \& Van Gennep, 231-241. Tempelman, O. (2020),

Dit zijn de zeven zondebokken van de coronacrisis, in: Volkrant.nl, 8 mei, https:// www.volkskrant.nl/nieuws-achtergrond/dit-zijn-de-zeven-zondebokken-van-decoronacrisis bc6ogea5/ [bezocht op o6-01-2021].

Tilley, T.W. (2000),

The evils of theodicy, Eugene: Wipf and Stock Publishers.

Thiessen, M.A. (2020),

The election is over. Can we finally blame China for the pandemic?, in: WashingtonPost. com, 8 december, https://www.washingtonpost.com/opinions/2020/12/o8/electionis-over-can-we-finally-blame-china-pandemic/ [bezocht op o6-01-2021]. 
Voermans, W. \& E. Jurgens (2020),

De vrijheid van religie kan ten koste gaan van de gezondheid van anderen, in: Volkskrant.nl, 2 december, https://www.volkskrant.nl/columns-opinie/opinie-devrijheid-van-religie-kan-ten-koste-gaan-van-de-gezondheid-van-anderen bf $516 \mathrm{c} 2 \mathrm{c} /$ [bezocht op o6-01-2021].

Vorwald, A. (2020),

Innovatie op de werkvloer, applaus voor hulpverleners en elkaar helpen: de positieve effecten van de coronacrisis op een rij, in: 1Vandaag.nl, 17 maart, https://eenvandaag. avrotros.nl/item/innovatie-op-de-werkvloer-applaus-voor-hulpverleners-en-elkaarhelpen-de-positieve-effecten-van-d/ [bezocht op o6-01-2021].

Weisman, A. (2020),

Is the coronavirus pandemic Mother Nature's revenge?, in: BostonGlobe.com, 22 april, https://www.bostonglobe.com/2020/04/22/magazine/is-coronavirus-pandemicmother-natures-revenge/ [bezocht op o6-01-2021].

Wieringen, Archibald L.H.M. van (2015),

The Biblical View Regarding Man: Biblical Anthropology and Man's Mission, in: Theology \& Life (Hong Kong: Lutheran Theological Seminary), 38, 3-29. 